\title{
CCDC26 wt Allele
}

National Cancer Institute

\section{Source}

National Cancer Institute. CCDC26 wt Allele. NCI Thesaurus. Code C134629.

Human CCDC26 wild-type allele is located in the vicinity of 8q24.21 and is approximately $329 \mathrm{~kb}$ in length. This allele, which encodes CCDC26 long non-coding RNA and/or putative coiled-coil domain-containing protein 26 , may play a role in the cellular response to retinoic acid. 